Article

\title{
Nutritional Status of Resident Female Orphans of Selected Orphanages of Dhaka City
}

\author{
Mahnaz Hussain ${ }^{1}$, A.M.M. Mokarram Hossain², Aminul Huq Bhuyan ${ }^{3}$
}

\begin{abstract}
Background: Malnutrition specially under nutrition has been recognized as the major cause of morbidity and mortality among children. The orphan children are the most vulnerable section to malnutrition in our society. Objective: To assess the nutritional status in relation to anthropometrical measurements, hemoglobin level \& clinical presentations of orphans of Dhaka City. Method: This nutritional survey was done under the supervision of Department of Nutrition, Institute of Nutrition and Food Science, Dhaka from November 2007 to January 2008. Total 179 female resident orphans aged 6-15 years from 2 orphanages named Alnahian Shishu Paribar and Ahsania Mission of Dhaka city were screened. They were assessed for BMI, Hb conc. and various clinical presentation of nutritional disorders. Data were analyzed by proportion test. Results: $60.3 \%$ of the total respondent's from both orphanages were below the standard BMI which was significantly higher $\mathrm{p}<0.001$ ) than that of 34.6\% respondents with normal BMI. The malnourished orphans were 63.2\% in Ahsania Mission and 58.3\% were in Alnalian Shishu Paribar Etimkhana. Mean \pm SD haemoglobin level of 116 children was $10.67 \pm 1.37 .59 .8 \%$ children had hemoglobin level less than $12.0 \mathrm{~g} / \mathrm{dl}$ and they were significantly higher than non anemic children $(\mathrm{P}<0.001)$. In Alnahian Shishu Paribar, 58.3\% respondants were malnourished, $49 \%$ were anemic, $1.9 \%$ orphan had goiter, $91.3 \%$ were suffering from respiratory tract infection, $3.9 \%$ had xeropthalmia, $18.4 \%$ were suffering from angular stomatitis, 29.1\% had cheliosis , 58.3\% had glossitis , 1.9\% had kwashiorkor and $1 \%$ were marasmic compared to those of $63.2 \%, 28.9 \%, 2.6 \%, 84.2 \%, 1.3 \%, 17.1 \%, 26.3 \%, 44.7 \%, 2.6 \%, 2.6 \%$ respectively in respondents of Ahsania Mission. The frequency of the deficiency diseases was almost similar in the two orphanages except anemia which was significantly higher in Ahsania Mission compared to that of Al Nahian. Conclusion: Significant percentage of orphans were undernourished and were suffering from various nutritional deficiency related disorders in both the etimkhaha \& anemia was predominant in Ahsania Mission.
\end{abstract}

Key words: malnutrition, BMI, Hb, anemia, orphan

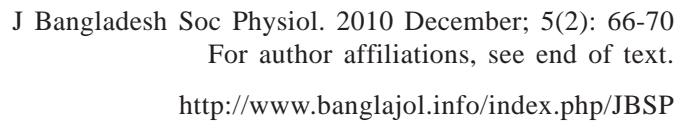

J Bangladesh Soc Physiol. 2010 December; 5(2): 66-70 For author affiliations, see end of text.

http://www.banglajol.info/index.php/JBSP

\section{Introduction}

$\mathbf{T}$ he nutritional status is determined by the kind and amount of nutrients supplied to the body and how

completely they are used to meet body needs. The nutritional status refers to the health of an individual as it is affected by the intake of food and its utilization. It is the condition of health of an individual influenced by the utilization of the nutrients. It can be determined only by the correlation of information obtained through a 
careful medical and dietary history and appropriate laboratory investigations ${ }^{1}$.

A survey of nutritional status should show the relationship between food and nutrients, their use in the body and general health. It may be good, fair or poor, depending on the body ability to utilize these. ${ }^{2}$. Nutritional status is affected when a person is deprived of adequate amount of essential nutrients over unexpended period of time. $^{3}$

Nutritional assessment is the process whereby the state of nutritional health of an individual or group of individuals is determined. Nutritional status is commonly assessed by anthropometrics measurement, clinical examinations for ascertaining nutritional deficiencies \&also biochemical assessment ${ }^{4}$. Results also show that women and children are the primary victims of malnutrition. ${ }^{5}$ Malnutrition have many adverse consequences. In young children prolonged malnutrition retards growth, increases illness and delays learning. It is often argued that a malnourished is mentally and physically fatigued. He lacks in curiosity and he is irresponsive to environmental situation. He is also frequently attacked by illness leading to higher absenteeism which is considered as another cause for poor performance. ${ }^{6}$ Malnutrition and undernutrition are also the major cause of morbidity and mortality among children. ${ }^{7}$

The orphan children are the most inseparable segment of our population. The carefully planned education environment, health and nutrition policy that address vital needs of these children is most important for a nation for the optimal physical, mental and emotional development of its future worthy citizens. The common sense view of a child is an individual not yet mature enough (physically intellectually or psychologically) to have outgrown the need for adult guidance and dependence. ${ }^{8}$

An orphan is a child whose parents are dead, who has been deprived of parental care, one that lacks support, supervision or care and who loss his/her home or address. ${ }^{9} \mathrm{~A}$ lack of parents creates characters that are self-contained and introspective and strive for affection. ${ }^{10}$

In the present context, it is more important to assess the nutritional status of the orphan children. As such the present study was undertaken to assess the nutritional status in relation to clinical presentations, anthropometrical measurements \& hemoglobin level in selected orphan children of two orphanages in Dhaka city.

\section{Methods}

This observational study was carried out to evaluate the nutritional status of orphans from two selected orphanages of Dhaka city during the period from November 2007 to January 2008. Total 183 female orphans, age ranged between 615 years were enrolled from one government run orphanage named Ahsanullah Etimkhana and one nongovernment orphanage, Al-Nahian Shisu Paribar. Then a questionnaire was developed according to the need of the study. The aim, objective and benefit of the study were explained to the authority of the two orphanages. An informed written consent and no objection from the authority of the orphanages were obtained. The study subjects were first interviewed then a questionnaire was distributed among them to fill up. Then the anthropometric data was collected by measuring weight (in $\mathrm{Kg}$ ) and height (in $\mathrm{cm}$ ) of the individual orphan child.

BMI was calculated by using the following formula:Wt (in kg) / Ht (in $\mathrm{m}^{2}$ ) = BMI (in $\mathrm{Kg} /$ $\mathrm{m}^{2}$ ). The Body Mass Index of the respondents was calculated and they were grouped according to WHO classification of BMI of adolescence and adult. ${ }^{\mathbf{1 1}}$

Estimation of blood hemoglobin level was incorporated in the questionnaire for biochemical assessment. Estimation of Hemoglobin level was done by the Sahli's Acid Hematin Method. ${ }^{12}$ 
Data on clinical presentations of the nutritional deficiency disorders like presence of anemia, goitre, RTI, xeropthalmia, angular stomatitis, cheliosis, glossitis, kwashiorkor and marasmus were included in the questionnaire. Data were expressed as percentages. For statistical analysis proportion test was used to observe the significant difference between frequencies in relation to BMI, blood hemoglobin \& clinical presentation of deficiency disorder. $\mathrm{P}<0.05$ was taken as level significance.

\section{Results}

Out of 183 initially enrolled respondents, six children were dropped as they were reluctant to continue and therefore data from 179 children were obtained for the study. Again, hemoglobin estimation of 116 children out of 179 was done due to panic of pricking pain of some children.

In this study, $60.3 \%$ of the total respondent's from both orphanages were below the standard BMI and 34.6\% respondents were with normal BMI ranged 18.5-24.99. (Table I). The difference was statistically significant $(\mathrm{p}<0.001)$. This findings indicate that a major percentages of the orphans were malnourished and at higher risk of developing nutritional health disorders. Data of two orphanages show that 58.3\% (60 out of 103)respondents of Alnahian and 63.2\% (48 out of 76) of Ahsanullah were malnourished. Again, mean \pm SD haemoglobin level of children of both orphanage was $10.67 \pm 1.37$ (Table II). 92.25\% children had less than $12.0 \mathrm{~g} / \mathrm{dl}$ blood haemoglobin level which is the cut off point ${ }^{13}$ of blood haemoglobin for this age group according to WHO, (1972) and indicate presence of anemia (Table III).

Information on clinical presentation was collected to identify nutritional deficiency disorder. Data of two orphanages showed that in Alnahian Shishu Paribar, 58.3\% respondant were malnourished, 49\% were anemic, 1.9\% orphan had goiter, $91.3 \%$ were suffering from respiratory tract infection, 3.9\% had xeropthalmia,18.4\% were suffering from angular stomatitis, $29.1 \%$ had cheliosis, $58.3 \%$ had glossitis, $1.9 \%$ was kwashiorkor, $1 \%$ were marasmic compared to $63.2 \%$, 28.9\% , 2.6\%, 84.2\%, 1.3\%, 17.1\%, 26.3\%, $44.7 \%, 2.6 \%, 2.6 \%$ respectively in respondents of Ahsanullah mission. (Table-IV) But the differences in all these clinical presentations between the two orphanages were not statistically significant( $\mathrm{p}>$.0.05)except anemia which was significantly higher $(p<0.01)$ in children of Ahsania Mission. Therefore, proportion of most of the deficiency diseases is almost similar in the two orphanages. Among the deficiency diseases highest prevalence rate was noted in RTI (88.3\%) followed by glossitis (52.5\%), anaemia (40.8\%), cheliosis (27.9\%) and angular stomatitis (17.9\%). Only 9.5\% had sign symptom of other deficiency diseases.

Table I: Distribution of the children by the body Mass Index $(\mathrm{n}=179)$

\begin{tabular}{lcccccccc}
\hline BMIKg/sqm & \multicolumn{2}{c}{ Alnahian Shishu Paribar } & & \multicolumn{2}{c}{ Ahsanullah Mission } & & \multicolumn{2}{c}{ Total } \\
\cline { 2 - 3 } & Frequency & Percent & & Frequency & Percent & & Frequency & Percent \\
\hline$<18.5$ & 60 & 58.3 & & 48 & 63.2 & & 108 & $60.3^{* * *}$ \\
$18.5-24.99$ & 38 & 36.9 & & 24 & 31.6 & & 62 & 34.6 \\
$25.0-29.99$ & 3 & 2.9 & 2 & 2.6 & & 5 & 2.8 \\
$>30.0$ & 2 & 1.9 & & 2 & 2.6 & & 4 & 2.2 \\
\hline Total & 103 & 100.0 & 76 & 100.0 & & 179 & 100.0 \\
\hline
\end{tabular}

$<18.5$ vs $\geq 18.5 \mathrm{p}<0.001^{* * *}$ 
Table II: Mean Blood haemoglobin level $(\mathrm{n}=116)$

\begin{tabular}{lcc}
\hline Age & Frequency & $\begin{array}{c}\text { Mean } \mathrm{Hb} \\
(\mathrm{g} / \mathrm{dl})\end{array}$ \\
\hline $6-15$ years & 116 & $10.67 \pm 1.37$ \\
\hline
\end{tabular}

Table III: Distribution of the children of the orphanages by the blood hemoglobin level $(\mathrm{n}=116)$

\begin{tabular}{lcc}
\hline Hb range $(\mathrm{g} / \mathrm{dl})$ & Frequency & Percent \\
\hline$<12$ & 107 & $92.25^{* * *}$ \\
$\geq 12$ & 9 & 7.75 \\
\hline Total & 116 & 100 \\
\hline$* * *=\mathrm{p}<0.001$ & &
\end{tabular}

Table IV: Distribution of the respondents by the presence of clinical sign symptoms of nutritional deficiency disorder in two orphanages $(n=179)$

\begin{tabular}{|c|c|c|c|c|c|c|}
\hline \multirow[t]{2}{*}{ Types of disorder } & \multicolumn{2}{|c|}{ Alnahian } & \multicolumn{2}{|c|}{ Ahsanullah } & \multicolumn{2}{|c|}{ Total } \\
\hline & Frequency & Percent & Frequency & Percent & Frequency & Percent \\
\hline Anaemia & 51 & 49.5 & 22 & $28.9^{*}$ & 73 & 40.8 \\
\hline Goiter & 2 & 1.9 & 2 & $2.6^{\mathrm{ns}}$ & 4 & 2.2 \\
\hline RTI & 94 & 91.3 & 64 & $84.2^{\mathrm{ns}}$ & 158 & 88.3 \\
\hline Xerophthalamia & 4 & 3.9 & 1 & $1.3^{\mathrm{ns}}$ & 5 & 2.8 \\
\hline Angular stomatitis & 19 & 18.4 & 13 & $17.1^{\mathrm{ns}}$ & 32 & 17.9 \\
\hline Cheliosis & 30 & 29.1 & 20 & $26.3^{\text {ns }}$ & 50 & 27.9 \\
\hline Glossitis & 60 & 58.3 & 34 & $44.7^{\mathrm{ns}}$ & 94 & 52.5 \\
\hline Kowashiorkor & 2 & 1.9 & 2 & $2.6^{\mathrm{ns}}$ & 4 & 2.2 \\
\hline Marasmus & 1 & 1.0 & 2 & $2.6^{\mathrm{ns}}$ & 3 & 1.7 \\
\hline Others & 14 & 13.6 & 3 & $3.9^{\text {ns }}$ & 17 & 9.5 \\
\hline
\end{tabular}

$*=\mathrm{p}<0.01 \mathrm{~ns}=$ non significant.

\section{Discussion}

The Body Mass Index (BMI) of the orphans was classified according to $\mathrm{WHO}^{11}$. According to this classification, $34.6 \%$ orphans were normal and have lowest risk of developing malnutrition. The malnourished orphans in Ahsania Mission were 63.2\% but in Alnahian it was 58.3\%. Again 41.7\% orphans of Alnahian had normal nutritional status whereas in Ahsania Mission this value was 36.9\% . In a similar study, Begum et al. found 23.89\% girls and $21.21 \%$ boys had normal nutritional status $^{15}$.

69
Average concentration of hemoglobin of the orphan girls were $10.67 \mathrm{~g} / \mathrm{dl}$. According to WHO, adolescent girls with a hemoglobin level below $12.0 \mathrm{~g} / \mathrm{dl}$ are considered anemic ${ }^{13}$. On the other hand, in a study on adolescent school girl suffering from nutritional anemia in Dhaka city Hyderi et al. reported that about $22 \%$ of the girls were anemic ${ }^{16}$. Others have shown $17 \%$ of the adolescent school girls of Dhaka city were anemic. ${ }^{17}$

The study revealed that the clinical presentations of nutritional deficiency disorders 
of the two orphanages were not good at all. 88.3\%, $52.5 \%$, $40 \%, 27.9 \%$, $17.9 \%$ of orphans were suffered from RTI, glossitis, anemia, cheilosis and angular stomatitis respectively. Only 9.5\% had sign and symptoms of other deficiency diseases. The frequency of occurrences of the deficiency diseases was almost similar in the two orphanages. The findings indicated that two thirds of the orphan girls had suboptimal intake of food for a long period of time and increasingly malnourished as they grow older as depicted by Tomkins in $1986 .^{14}$

\section{Conclusion}

Our study evaluated the nutritional status including physical, biochemical and clinical parameters. Their mean hemoglobin level and the BMI were below the normal cut off point. A large number of orphans suffered from RTI, glossities, anemia, cheliosis and angular stomatitis.

The clinical, anthropometric and biochemical management of such orphans are very much important and will have better impact on growth and development.

\section{Acknowledgement}

Authors of the study are thankful to the authorities and orphans of Alnahian Shishu Paribar Etimkhana and Ahsania Mission Etimkhana for their co operation while conducting this research work.

\section{Author's affiliation}

1. Mahnaz Hussain, Email:rimu170@yahoo.com

2. AMM Mokkaram Hossain, Professor, Institute of Nutrition and Food Science, Dhaka University

3. Aminul Huq Bhuyan- Professor, Institute of Nutrition and Food Science, Dhaka University

\section{References}

1. Christakis GE. Nutritional Assessment in Health Programs. Am J Public Health. 1975; 63: 11.

2. Overt JC. Community Nutrition. $5^{\text {th }}$ ed. John Wiley Sons Inc; Canada: 1980. pp15-24.

3. Robinson $\mathrm{CH}$ and Maylyn RL. Normal and therapeutic Nutrition. $16^{\text {th }}$ ed. Macmillan Publishing Co Inc;Philadelphia: pp.393-404.
4. Committee on Goals of Education for Dietetics. Goals of the Lifetime Education of the Dietitian. J. Am. Diet. Assoc. 1969;54: 92.

5. Rahman KM. \& Awal A.MMA. Nutrition and Poverty. In:Proceedings of the $7^{\text {th }}$ Conference of Bangladesh Nutritional society; 1997March 1517; Dhaka

6. Berg A. The Nutrition Factor. $7^{\text {th }}$ ed.The Brookings institute; Massachusettes:1969.p45

7. Hartman B. and James K. Needles Hunger: Voices from a Bangladeshi Village. Institute for Food and Development Policy. 1979.p56

8. Alson P. The Best interests of the Child: Reconciling Culture and Human Rights. UNICEF-ICDC, Oxford Clarendon Press; Boston: 1994.pp32-35

9. The American Heritage Dictionary of the English Language. $4^{\text {th }}$ ed. Houghton company ltd; Houston: 1987.p459

10. FAO/WHO/UNU Expert Consultation. Energy and protein requirements. World Health Organization, Geneva. 1985.Report no. WHO Technical Report Series 724 .

11. Gorstin J, Sullivan K, Yip R, Onis De M, Trowbridge F, Fajams P, Clugston G. Issues in the assessment of nutritional status using anthropometry. Bull World Health Organ. 1994; 72(2) : 273-83.

12. Ghai CL .Textbook of Practical Physiology.7th ed. Jaypee Brothers Medical publishers Ltd; New Delhi: 2007.p 38

13. WHO Chronicle no 20-81, 1972

14. Tomkins AM. Dun DT. Hayes RJ and Bradley AK. Seasonal variations in the nutritional status of urban Gambian children. Br. J. Nutr. 1986; 56: 53343

15. Begum JA and Hague AASM. A Study of the Health \& Nutritional Status of Children in rural Bangladesh. Journal of preventive and social medicine. 1992; 2:45-48.

16. Hyderi T. Studies on nutritional anemia in adolescent girls.[M.Sc. thesis][Dhaka].Institute of Nutrition and Food Science, University of Dhaka; 1993.

17. Begum N. Needs and availability of nutrients for adolescents' girls. [MSc thesis] [Dhaka]. Institute of Nutrition and Food Science. University of Dhaka; 1993. 